Jurnal Riset Pendidikan Dasar

1 ( 1), ( 2018) 1-9

Submitted: Januari, Accepted: Maret, Published: April

\title{
PENGARUH KEDISIPLINAN BELAJAR TERHADAP HASIL BELAJAR MATEMATIKA SISWA DI SEKOLAH DASAR
}

\author{
Rusni*, Agustan \\ Program Studi Pendidikan Dasar, Pascasarjana Universitas Muhammadiyah Makassar, Indonesia \\ *Korespondensi. E-mail: Rusnie090@yahoo.com
}

\begin{abstract}
Abstrak
Kedisiplinan belajar merupakan hal yang penting dalam belajar. Penelitian ini bertujuan untuk mengetahui hubugan kedisiplinan belajar terhadap hasil belajar matematika siswa. Menggunakan metode ex post facto karena eksistensi dari variabel yang diteliti telah terjadi. Hasil penelitian menggunakan analisis statatistik deskriptif menunjukkan bahwa rata-rata hasil kedisplinan siswa adalah 72,22 dan tergolong cukup tinggi, rata-rata hasil belajar matematika siswa adalah 77,97 tergolong tinggi. Hasil penelitian mengunakan korelasi Pearson Product Moment menunjukkan nilai $r_{\text {hitung }} 0,799$ lebih besar dari nilai $r_{\text {tabel }}$ untuk $\mathrm{n}=36$ yaitu 0,329 berarti terdapat pengaruh kedisiplinan belajar terhadap hasil belajar siswa di SD Negeri Nusa Harapan Permai Kota Makassar yang menjadi populasi. Hasil uji signifikan dengan a $5 \%$ diperoleh $t_{\text {hitung }}$ 7,746 lebih besar dari $t_{\text {tabel }} 1,691$, ini berarti terdapat pengaruh yang signifikan kedisiplinan belajar terhadap hasil belajar Matematika siswa di SD Negeri Nusa Harapan Permai Kota Makassar. Pada hakekatnya kedisiplinan adalah hal yang dapat dilatih. Penelitian ini dapat menjadi acuan dalam melatih kedisiplinan siswa. Salah satu hal yang dapat dilakukan adalah membiasakan anak untuk mengaktifkan diri dengan nilai-nilai moral untuk memiliki dan mengembangkan disiplin diri. Hal ini sesuai dengan teori Shochib.
\end{abstract}

Kata Kunci: Kedisiplinan, Hasil Belajar Matematika, Sekolah Dasar

\section{THE INFLUENCE OF LEARNING CYLINARY ON STUDENT LEARNING RESULTS IN SCHOOL BASIC SCHOOL}

\begin{abstract}
Discipline learning is an important thing in learning. This study aims to find out the hubugan discipline of learning on student learning outcomes mathematics. Using the ex post facto method because the existence of the variables studied has occurred. The result of the research using descriptive statistical analysis showed that the average of disciplinary result of students was 72.22 and quite high, the average of students' mathematics learning result was 77,97 was high. The result of the research using Pearson Product Moment correlation shows the value of rs 0,799 bigger than rtabel value for $n=36$ that is 0,329 mean there is influence of learning discipline to student learning result at SD Negeri Nusa Harapan Permai Kota Makassar become population. Significant test results with $\alpha 5 \%$ obtained tcount 7.746 greater than $\mathrm{t}$ table 1.691 , this means there is a significant effect of learning discipline on student learning outcomes in Elementary School Nusa Harapan Permai Makassar City. In essence, discipline is something that can be trained. This research can be a reference in training student discipline. One of the things that can be done is to familiarize children to activate themselves with moral values to own and develop self-discipline. This is in accordance with Shochib's theory.
\end{abstract}

Keywords: Discipline, Mathematics Learning Outcomes, Primary School 


\section{PENDAHULUAN}

Sekolah adalah salah satu tempat formal untuk melangsungkan proses belajar mengajar. Untuk menciptakan suasana belajar yang kondusif, sekolah perlu menetapkan tata tertib sekolah. Hasil penelitian menunjukkan bahwa kedisiplinan belajar berpengaruh terhadap prestasi belajar siswa (Mahardika, 2011; Saputro 2015). Tata tertib dan kedisiplinan sangat penting artinya dalam mewujudkan budaya dan iklim sekolah yang kondusif melalui penciptaan kedisiplian belajar (Daryanto, 2015: 83). Salah satu faktor penentu keberhasilan dalam pembelajaran adalah disiplin siswa (Kompri, 2014: 274).

Disiplin dapat mengatur tatanan kehidupan dalam belajar meliputi ketaatan (kepatuhan) terhadap peraturan tata tertib dan sebagainya (Kompri, 2014: 59). Disipilin merupakan perilaku yang muncul karena kesadaran dan kerelaan sebagai bentuk ketaatan pada peraturan dan sanksi yang berlaku dalam lingkungan sekolah (Daryanto, 2015: 22). Perilaku disiplin baik itu perorangan, kelompok atau masyarakat merupakan sikap mental yang tercermin melalui perbuatan berupa ketaatan terhadap peraturan, norma atau kaidah yang berlaku dalam masyarakat itu sendiri untuk mencapai tujuan tertentu (Sulistyani, 2011: 328).

Salah satu upaya penting yang dapat dilakukan agar perilaku anak sesuai dengan aturan sehingga membentuk perilaku anak adalah dengan mengundang anak-anak untuk mengaktifkan diri dengan nilai-nilai moral untuk memiliki dan mengembangkan disiplin dir. Kesadaran diri akan tugas dan tanggungjawab serta kemampuan seseorang untuk patuh atau taat terhadap peraturan yang berlaku adalah bentuk disiplin diri (Shochib, 2000:11). Disiplin diri tidak dapat dibangun tanpa pembiasaan. Kerjasama antara pihak sekolah dan keluarga sangat berperan dalam membangun sikap disiplin siswa. Di sekolah guru perlu memonitor siswa terhadap pelanggaran-pelanggaran disiplin dalam hal ini pelanggaran yang terjadi dalam proses belajar ataupun yang mengganggu berlangsungnya proses belajar mengajar. Guru perlu secara tegas menyampaikan apa saja yang menjadi tanggungjawab siswa di sekolah dalam kaitannya dengan proses belajar. Sosialisasi mengenai tata tertib di sekolah dan khususnya di dalam kelas perlu dilakukan agar siswa mengetahui hal-hal apa saja yang bisa dilakukan di dalam kelas selama proses belajar mengajar dan hal yang tidak bisa dilakukan. Membuat peraturan yang jelas dan tegas agar siswa dan lingkungannya dapat melaksanakan dengan sebaik-baiknya (Mulyasa, 2005: 140). Selain itu, guru perlu senantiasa mengingatkan siswa mengenai tugas sekolah yang harus dikerjakan di rumah.

Terdapat langkah-langkah pendekatan sistem disiplin secara menyuruh seperti merumuskan dengan jelas bentuk perilaku yang diharapkan, diajarkan dalam konteks yang sesungguhnya, dihargai secara teratur dan perilaku yang menyimpang dikoreksi dengan proaktif menggunakan prosedur yang jelas (Aqib, 2011: 19). Warga sekolah secara bersama perlu mendukung sistem disiplin tersebut. Saat siswa berada di rumah, peran serta orang tua di rumah sangat dibutuhkan untuk mengarahkan anak-anaknya mengerjakan sendiri apa yang seharusnya menjadi tanggungjawabnya sebagai seorang anak dan sebagai seorang siswa yang tentunya punya tanggungjawab untuk belajar.

Disiplin merupakan upaya untuk membuat orang berada pada jalur sikap dan perilaku yang sudah ditetapkan pada individu oleh orang tua. Hal sederhana yang bisa membantu anak untuk terbiasa disiplin adalah menyiapkan sendiri buku-buku pelajaran sekolahnya setiap hari. Kegiatan ini harus dilakukan secara rutin, peran serta atau kontrol orang tua dalam hal ini sangat diperlukan. Dalam dunia pendidikan, kedisiplinan dalam belajar sangat penting. Bentuk kedisiplinan belajar di sekolah antara lain adalah tanggungjawab siswa dalam mengerjakan tugas-tugas yang diberikan oleh guru dan menyelesaikannya tepat waktu, masuk kelas saat bel berbunyi, mengikuti pelajaran dengan tenang dan, memperhatikan penjelasan dari guru. Bentuk kedisiplinan belajar di rumah antara lain adalah mengerjakan PR yang 
diberikan oleh guru dengan baik dan rasa tanggungjawab, menyiapkan buku-buku pelajaran sesuai roster belajar.

Pada jenjang sekolah dasar, banyak sekali permasalahan yang sering terjadi yang dapat mengganggu proses belajar mengajar. Salah satunya adalah masalah kedisiplinan belajar. Saat berkunjung ke sekolah, peneliti mengamati terjadi beberapa pelanggaran terhadap kedisiplinan, setelah mengamati beberapa hari saat guru sedang mengajarkan matematika dan melakukan wawancara dengan guru, ternyata matematika salah satu mata pelajaran yang nilainya tidak mencapai KKM, beberapa siswa sering tidak mampu menyelesaikan tugas sampai jam pelajaran seesai dan terkadang PR dikerjakan di sekolah. Keadaan seperti ini kerap dijumpai pada saat berlangsungnya proses belajar mengajar beberapa siswa asyik bermain atau bercerita dengan temannya, padahal tugas yang diberikan oleh gurunya belum selesai. Ini berarti belum ada kesadaran bagi sebahagian siswa akan tanggungjawab terhadap tugas yang diberikan. Situasi seperti ini dapat menimbulkan hasil belajar yang rendah karena siswa tidak fokus pada tugas yang dikerjakannya. Penelitian menujukkan bahwa prestasi belajar matematika pada siswa yang memiliki kedisiplinan belajar tinggi lebih baik daripada siswa dengan kedisiplinan belajar sedang dan rendah. (Anas, 2013).

Peneliti beranggapan bahwa matematika adalah salah satu mata pelajaran yang membutuhkan ketekunan dan disiplin belajar yang tinggi untuk dapat memahaminya. Ketika siswa tidak memahami rumus dan materi yang disampaikan maka, siswa akan kesulitan menjawab soal-soal. Rumus-rumus untuk mengerjakan soal-soal matematika itu dikerjakan dengan runtut, apabila pada bagian tengah pengerjaannya salah maka hasilnya akan salah. Hasil penelitian menunjukkan bahwa disiplin mengerjakan tugas berpengaruh signifikan terhadap prestasi belajar matematika (Wahyuni, 2014). Membiasakan siswa berperilaku disiplin merupakan hal penting agar siswa terbiasa berperilaku dan mengerjakan sesuatu sesuai dengan waktu dan aturannya.

Disiplin merupakan langkah-langkah yang perlu guru, kepala sekolah, orangtua, dan siswa ikuti untuk mengembangkan keberhasilan perilaku siswa baik akademik maupun sosial (Aqib, 2011: 118). Tata tertib yang ada di sekolah harus dilaksanakan secara konsisten dan diberlakukan kepada seluruh stake holder yang ada di sekolah (Daryanto, 2015: 84). Faktor utama yang dapat menunjang proses belajar yang baik adalah tegaknya disiplin sekolah yang diberlakukan secara konsisten (Kompri, 2014: 63).

Perilaku disiplin merupakan sesuatu hal yang dapat dilatih. Siswa perlu dibiasakan untuk bekerja dan bersikap berdasarkan aturan. Guru, kepala sekolah dan seluruh stake holder sekolah harus mampu menjadi model atau teladan bagi penegakan disiplin dan tata tertib sekolah (Daryanto, 2015: 88). Dengan demikian, siswa akan belajar bahwa kedisiplinan merupakan hal yang sangat penting untuk dilakukan. Peran orang tua sangat penting dalam membiasakan siswa untuk berperilaku disiplin di rumah. Perilaku siswa yang terbiasa melakukan segala sesuatu berdasakan aturan yang ada di rumah dapat melatih siswa untuk disiplin sehingga, kebiasaan itu dapat terbawa ketika siswa berada di sekolah.

Disiplin mengacu pada pola tingkah laku dan ciri-ciri seperti: 1) adanya hasrat yang kuat melaksanakan sepenuhnya apa yang sudah menjadi norma, etik dan kaidah yang berlaku, 2) adanya perilaku yang dikendalikan dan 3) adanya ketaatan (Sulistyani, 2011: 328). Berdasarkan teori di atas dapat dipahami bahwa kedisiplinan adalah pola perilaku seseorang yang terbentuk dari proses bimbingan atau arahan untuk dapat memahami, mematuhi dan taat menjalankan segala aturan-aturan, norma-norma, kaidahkaidah atau tata tertib yang berlaku baik yang ditetapkan oleh individu maupun kelompok.

Belajar adalah terjadinya perubahan persepsi dan perilaku termasuk didalamnya perbaikan perilaku (Hamalik, 2010: 45). Belajar adalah aktivitas yang dilakukan untuk menndapatkan perubahan dalam diri seseorang melalui pelatihan atau pengalaman baik perubahan pengetahuan, sikap maupun keterampilan agar dapat memecahkan masalah dalam kehidupan serta mampu menyesuaikan diri dengan lingkungannya (Baharuddin, 2010: 158). Perubahan perilaku sebagai hasil dari pengalaman belajar relatif permanen dan

Copyright (O2018, JRPD, ISSN 2615 - 1723 (Print), ISSN 2615 - 1766 (Online) 
mampu mengomunikasikannya kepada orang lain (Pidarta, 2014: 209).

Salah satu faktor yang berpengaruh dan berperan penting dalam pembentukan pribadi dan perilaku individu adalah belajar (Yudhawati, 2011: 32). Sebagian besar perkembangan individu berlangsung melalui kegiatan belajar (Sukmadinata dalam Yudhawati, 2011: 32). Prinsip-prinsip belajar meliputi: 1) Kontiguitas, memberikan situasi atau materi yang sesuai harapan pendidik tentang respon anak yang diharapkan; 2) Pengulangan, situasi dan respon anak diulangulang agar belajar lebih sempurna dan lama dingat; 3) Penguatan, respon yang benar misalnya diberi hadiah untuk mempertahankan dan menguatkan respon itu; 4) motivasi positif dan percaya diri dalam belajar; 4) tersedia materi pelajaran yang lengkap untuk memancing aktivitas anak; 5) ada upaya untuk membangkitkan keterampilan intelektual untuk belajar, seperti apersepsi dalam mengajar; 6) ada strategi yang tepat untuk mengaktifkan anak-anaka dalam belajar; 7) aspek-aspek jiwa anak harus dapat dipengaruhi oleh faktor-faktor dalam pengajaran. (Gagne 1979 dalam Pidarta, 2014: 209)

Berdasarkan beberapa penjelasan ahli tersebut, dapat dipahami bahwa belajar suatu usaha yang dilakukan seseorang dalam rangka memperoleh pengetahuan melibatkan aktivitas mental dan fisik melalui pelatihan dan pengalaman yang mempunyai dampak bagi perubahan perilakunya, sebagai hasil dari pengalaman dan interaksinya dengan lingkungannya. Dalam aktivitas belajar tersebut banyak faktor yang mempengaruhi yaitu: 1) faktor-faktor yang berasal dari luar diri meliputi a) faktor-faktor nonsosial, misalnya keadaan udara, suhu udara, cuaca, waktu, tempat, serta alat yang dipakai untuk belajar; b) faktor-faktor sosial, contohnya faktor manusia, baik manusia itu hadir, maupun kehadirannya itu dapat disimpulkan. Misalnya kalau satu kelas murid sedang mengerjakan ujian, lalu terdengar banyak anak-anak lain bercakap-cakap di samping kelas. 2) Faktor-faktor yang berasal dari dalam diri pelajar meliputi: a) faktor fisiologis, mislanya keadaan fungsi pancaindera; b) faktor-faktor psikologi, yaitu hal-hal yang mendorong aktifitas belajar itu, hal yang merupakan alasan dilakukan perbuatan belajar itu (Suryabrata, 2012: 233-236).

Disiplin adalah sikap atau perilaku seseorang untuk bertindak sesuai dengan aturan, norma, kaidah atau tata tertib yang berlaku. Dalam melakukan aktivitas pembelajaran, kedisiplinan sangat diperlukan. Siswa yang disiplin akan mengikuti pembelajaran di kelas dengan tepat waktu dan mematuhi segala aturan-aturan yang ditetapkan di dalam kelas sehingga proses pembelajaran dapat berlangsung dengan efektif dan efisien. Hal ini tentu dapat berimplikasi terhadap hasil belajar. Hal ini sejalan dengan hasil penelitian Saputro (2015) yang menyatakn bahwa kedisiplinan belajar berpengaruh positif terhadap prestasi belajar siswa.

Kedisiplinan belajar akan menghindarkan siswa dari menunda-nunda menyelesaikan tugas sekolah sehingga tidak ada pelajaran yang terabaikan. Tentunya, orang tua di rumah juga memegang peranan yang sangat penting dalam mengajarkan anaknya tentang kedisiplinan dengan kaitannya sebagai seorang siswa yang mempunyai tanggunjawab terhadap tugas belajarnya. Orang tua sedapat mungkin memantau aktivitas anaknya di rumah agar waktu yang dimiliki anak tidak hanya digunakan untuk bermain, apalagi dihabiskan untuk nonton atau sekedar bermain game.

Kebiasaan disiplin yang diperoleh siswa dari didikan orang tuanya di rumah akan berbagi hal nantinya akan sangat membantu siswa dalam menerapkan disiplin di sekolah maupun di lingkungan masyarakat. Kebiasaan disiplin belajar di rumah akan membuat siswa terhindar dari tidak menyelesaikan tugas sekolah. Kebiasaan disiplin di sekolah akan membuat siswa tidak ketinggalan materi pelajaran karena datang tepat waktu dan membantu anak dalam memahami pelajaran karena dapat mendengarkan penjelasan dari Copyright (C2018, JRPD, ISSN 2615 - 1723 (Print), ISSN 2615 - 1766 (Online) 


\section{Jurnal Riset Pendidikan Dasar, 01 ( 1), April 2018 ( 1-9)}

Rusni, Agustan

guru sehingga memudahkan siswa menyelesaikan tugas-tugas belajarnya. Dengan demikian, siswa akan mendapatkan hasil belajar yang baik.

\section{METODE}

Penelitian ini menggunakan metode $E x$ Post Facto. Metode Ex Post Facto atau disebut penelitian kausal komparatif adalah penelitian dengan mengadakan penyelidikan empiris sistematis dengan tidak mengendalikan variabel bebas secara langsung karena eksistensinya telah terjadi dan karena fenomena sukar dimanipulasi (Kerlinger, 1973 dalam Emzir 2015; Siregar, 2012: 103). Hubungan kausal adalah hubungan yang bersifat sebab akibat, terdapat variabel independen dan variabel dependen (Sugiyono,2014: 37).

Desain penelitian yang digunakan pada penelitian ini menggunakan desain koreasional. Penelitian korelasional bermaksud "mendeteksi sejauh mana variasi-variasi pada suatu faktor berhubungan dengan variasivariasi atau lebih faktor lain berdasarkan pada koefisien korelasinya" (Suryabrata, 2003: 82). Variabel independen (bebas) dalam penelitian ini adalah kedisplinan belajar. Pada penelitian ini, yang menjadi variabel bebas adalah kedisiplinan belajar. Variabel dependen (terikat) adalah hasil belajar.

Populasi dalam penelitian ini adalah seluruh siswa kelas IV, V dan VI SD Negeri Nusa Harapan Permai Kota Makassar yang berjumlah 72 orang. Populasi hanya ditentukan tiga kelas dengan asumsi bahwa : a) karena terbatasnya waktu penelitian b) siswa kelas satu belum pandai membaca memahami dan kedisiplinan belajarnya belum dapat diukur karena siswa baru, c) karakteristik banyak muncul pada kelas populasi.

Teknik pengambilan sampel pada penelitian ini adalah menggunakan teknik NonProbability sampling yaitu Sampling Sistematis. Teknik pengambilan sampel berdasarkan urutan dari anggota populasi yang telah diberi nomor urut. Sampel diambil kelas tinggi yaitu kelas IV, V dan VI dan akan dipilih berdasarkan urutan bilangan ganjil tiap kelas setelah disusun sehingga jumlah sampel yaitu 36 siswa. Selain itu, karakteristik variabel yang akan diteliti dapat diamati atau muncul pada sampel tersebut. Agar penelitian dapat berjalan dengan baik maka, ditetapkan prosedur penelitian sebelum kelapangan. Adapun prosedur penelitian adalah:

\section{Melakukan Observasi Awal}

Sebelum merumuskan judul dalam penelitian ini, maka terlebih dahulu peneliti mengadakan observasi awal di sekolah dengan mewawancarai salah seorang guru yang ada di sekolah tersebut pada tanggal 30 Maret 2016. Informasi yang peneliti peroleh selanjutnya dipelajari kemudian ditentukan variabel yang akan diteliti.

2. Menentukan Populasi dan Sampel

Setelah variabel penelitian ditentukan, selanjutnya ditentukan populasi dan sampel penelitian.

3. Menyusun Instrument Penelitian

Instrument penelitian disusun berdasarkan indikator dari variabel yang akan diteliti atau variabel yang mempengaruhi dalam hal ini kedisiplinan belajar

4. Menyebarkan Angket kepada Responden Instrument yang telah disusun berupa angket selanjutya disebarkan kepada responden yang telahditentukansebagaisampeldalampeneliti nini.

\section{Menganalisis Data}

Data yang telah dikumpulkan melalui angket selanjutnya di analisis menggunakan statistik.

6. Membuat Generalisasi

Berdasarkan data yang dianalsisi, peneliti akan membuat generalisasi atau menarik kesimpulan sesuai hipotesis yang diajukan

Penelitian menggunakan angket atau kuesioner sebagai instrument untuk mengukur kedisiplinan siswa. Kuesioner merupakan teknik pengumpulan data yang dilakukan dengan memberikan seperangkat pertanyaan tertulis kepada responden untuk dijawab. Kuisioner atau angket adalah salah satu teknik pengumpulan data dengan cara membuat Copyright (C2018, JRPD, ISSN 2615 - 1723 (Print), ISSN 2615 - 1766 (Online) 
seperangkat pertanyaan yang ditujukan kepada responden yang menjadi objek penelitian. Jenis kuesioner yang akan dipakai dalam penelitian ini adalah kuesioner tertutup yaitu bentuk pertanyaan yang diberikan kepada responden dilengkapi dengan jawaban dalam bentuk soal pilihan ganda. Pada kuisioner ini, setiap pertanyaan memiliki lima alternatif jawaban. Kuisioner ini tidak memungkin responden untuk memberikan alasan terhadap jawaban yang dipilih. Responden hanya akan memilih satu jawaban yang sesuai dengan karakteristik dirinya dengan cara memberikan tanda silang (x) atau tanda checklist $(\sqrt{ })$

Karena dalam penelitian yang menjadi focus penelitian dengan menggunakan kuisioner adalah sikap disiplin siswa maka, pertanyaan-pertanyaan dalam angket seputar kedisiplinan siswa yang berkaitan dengan kegiatan belajar atau proses pembelajaran secara langsung maupun tidak langsung, baik di rumah maupun di sekolah. Pertanyaanpertanyaan dalam angket tersebut dimaksudkan untuk memperoleh data berupa jawaban-jawaban yang nantinya dapat digunakan untuk membuat kesimpulan mengenai kedisiplinan belajar siswa. Untuk mengumpulkan informasi tentang hasil belajar digunakan dokumentasi. Dokumen tersebut nantinya akan digunakan untuk mengkorelasikan antara kedisiplinan belajar dengan hasil belajar matematika siswa setelah data mengenai kedisiplinan belajar siswa telah ada melalui penyebaran kuisioner dan telah dianalisis.

Teknik analisis data mengguakan statistik deskriptif dan Korelasi Pearson Product Moment. Statistik deskriptif digunakan untuk menggambarkan data yang telah terkumpul sebagaimana adanya dan tidak bermaksud membuat kesimpulan yang berlaku secara umum berdasarkan data tersebut. Untuk mendapatkan gambaran mengenai disiplin belajar dan hasil belajar peserta didik maka terlebih dahulu dibuat daftar mengenai hasil belajar dan kedisiplinan belajar siswa setelah hasil instrument penelitian dianalisis. Teknik analisis Pearson Product Moment digunakan karena hipotesis penelitiannya berbentuk hipotesis assosiatif dan data yang akan dikorelasikan berbentuk interval atau rasio. Untuk menghitung korelasi antara variabel $\mathrm{X}$ dan Variabel Y maka sebelumnya dibuat tabel penolong. Yaitu tabel yang menunjukkan data antara lain mengenai hasil belajar (X), kedisiplinan belajar siswa(Y), mean dari hasil belajar siswa, mean dari disiplin belajar siswa, hasil kali dari kedua variabel dan lainnya yang nantinya akan digunakan untuk mencari koefisien korelasinya.

\section{HASIL DAN PEMBAHASAN}

Penelitian yang bertempat di SD Nusa Harapan Permai ini mengambil tiga kelas sebagai sampel penelitian dengan prosedur pengambilan sampel sistematis. Berdasarkan hasil penelitian yang telah dilakukan, diperoleh data mengenai kedisiplinan belajar siswa yang diukur menggunakan angket tertutup. Selanjutnya hasil penelitian ini akan dipaparkan dan dianalisis dengan Statistik Deskriptif dan Korelasi Pearson Product Moment.

\section{a. Analisis Statistik Deskriptif}

\section{Kedisipilinan Belajar}

Data yang diperoleh dari hasil angket selanjutnya ditabulasi. Distribusi hasil angket mengenai jawaban responden terhadap setiap item nomor pertanyaan mengenai kedisiplinan belajar dapat dilihat pada tabel distribusi jawaban responden (terlampir). Selanjutnya dari hasil tabulasi distribusi jawaban responden untuk setiap item nomor pertanyaan mengenai kedisiplinan belajar, dianalisis untuk mengetahui interval- interval nilai dan besarnya frekuensi serta rata-rata skor hasil belajar. Data hasil penelitian yang telah dianalisis menunjukkan bahwa besarnya frekuensi untuk interval 58 - 62 sebanyak 5 orang, interval 63 - 67 sebanyak 3 orang, interval 68 - 72 sebanyak 7 orang, interval $73-$ 77 sebanyak 14 orang, interval $78-82$ sebanyak 6 orang dan interval $83-87$ sebanyak 1 orang. Berdasarkan analisis distribusi skor kedisiplinan belajar diperoleh rata-rata hasil belajar yaitu 72,22 . Skor ini 
tergolong tinggi dari skor ideal yang mungkin dicapai yaitu 100 .

Skor rata-rata kedisiplinan belajar siswa adalah 72,22. Skor ini terbilang cukup baik dari skor maksimal yang mungkin dicapai yaitu 100. Skor tertinggi kedisiplinan siswa adalah 83 dan skor terendah adalah 58 dengan standar deviasi 7,16 yang berarti bahwa skor kedisiplinan siswa yang menjadi populasi di SD Negeri Nusa Harapan Permai Kota Makassar tersebar dari skor terendah 58 sampai skor tertinggi 83.

Berdasarkan hasil perhitungan, siswa dengan kategori kedisiplinan belajar sangat rendah yaitu 6 siswa $(16,66 \%)$, siswa dengan kategori kedisiplinan rendah ada 5 siswa (13,38\%), kategori sedang dengan frekuensi 14 siswa $(38,88 \%)$, kategori tinggi dengan frekuensi 9 siswa (25\%), dan kategori kedisiplinan sangat tinggi dengan frekuensi 2 (5,55\%). Data menunjukkan kedisiplinan belajar siswa tergolong tinggi karena perbandingan banyak siswa pada kategori dibawah rata-rata dengan di atas rata-rata, lebih banyak pada kategori kedisiplinan diatas rata-rata.

\section{Hasil Belajar}

Dari dokumentasi mengenai hasil belajar siswa ynag berhasil dihimpun, diperoleh distribusi skor/nilai hasil belajar yang menjadi sampel di SD Negeri Nusa Harapan Permai Kota Makassar. Distribusi skor hasil belajar menunjukkan bahwa jumlah frekuensi hasil belajar siswa SD Negeri Nusa Harapan Permai Kota Makassar yang menjadi sampel adalah 36 yang berarti bahwa sampel yang diambil adalah 36 pula. Adapun skor rata-rata hasil belajar siswa dan standar deviasinya yaitu 77,97 dan standar deviasinya 5,68. Hasil analisis menunjukkan skor rata-rata hasil belajar siswa SD Negeri Nusa Harapan Permai Kota Makassar yang menjadi sampel adalah 77,97. Skor tersebut tergolong tinggi dari skor maksimal yang mungkin dicapai yaitu 100 . Tidak ada siswa yang hasil belajarnya berada pada kategori sangat rendah dan rendah $(0 \%)$. Selanjutnya 1 siswa pada kategori sedang (3\%),
30 siswa pada kategori tinggi (83\%) dan 5 siswa pada kategori sangat tinggi (14\%). Hasil belajar siswa tergolong tinggi karena besarnya frekuensi belajar siswa rata-rata berada pada kategori tinggi dan sangat tinggi. Sembilan puluh tujuh persen siswa memperoleh hasil belajar yang baik, dan tiga persennya memperoleh hasil belajar yang kurang baik.

Berdasarkan kategori, dapat disimpulkan bahwa hasil belajar siswa tergolong tinggi yaitu mencapai $83 \%$ dari hasil maksimal yang mungkin dicapai yaitu $100 \%$. Untuk mengetahui besarnya pengaruh kedisiplinan belajar terhadap hasil belajar siswa seperti yang dipaparkan pada hipotesis penelitian maka selanjutnya akan dianalisis menggunakan analisis Korelasi Pearson Product Moment.

\section{Analisis Korelasi Pearson Product Moment}

Untuk menguji hipotesis dalam penelitian ini digunakan rumus dari Pearson yaitu Korelasi Product Moment. Nilai hasil kedisiplinan belajar dan hasil belajar selanjutnya dianalaisis sesuai langkah-langkah rumus Korelasi Product Moment. Hasil olah data menunjukkan rhitung sebesar 0,799. Untuk mengetahui apakah kedisiplinan berpengaruh terhadap hasil belajar, maka nilai rhitung dibandingkan dengan nilai rtabel Product Moment diperoleh $\mathrm{n}=36$ maka nilai rabel yaitu 0,329. Hasil olah data menunjukkan nilai rhitung $>r$ tabel ini berarti terdapat pengaruh kedisiplinan belajar terhadap hasil belajar matematika siswa. Penelitian lain menunjukkan hasil yang sama yaitu kedisiplinan belajar berpengaruh terhadap hasil belajar matematika siswa (Safitri: 2012). Berpatokan pada tabel interpretasi koefisien korelasi nilai $r$, pengaruh kedisiplinan belajar terhadap hasil belajar pada populasi tergolong kuat.

Berdasarkan hasil olah data di atas, diperoleh thitung sebesar 7,746. Untuk mengetahui tingkat signifikannya maka, nilai thitung dibandingkan dengan nilai ttabel dengan $\mathrm{dk} \mathrm{n}-2=36-2=34$, diperoleh ttabel $=$ 1,691 . Ini berart nilai thitung $>$ ttabel maka $\mathrm{H} 0$ ditolak dan $\mathrm{H} 1$ diterima. Copyright (C2018, JRPD, ISSN 2615 - 1723 (Print), ISSN 2615 - 1766 (Online) 


\section{Jurnal Riset Pendidikan Dasar, 01 ( 1), April 2018 ( 1-9) \\ Rusni, Agustan}

Data hasil penelitian dengan menggunakan angket kedisiplinan, setelah diolah dengan statistik menunjukkan bahwa rata-rata kedisipilinan belajar siswa yaitu sebesar 72,22. Hal ini berarti rata-rata kedisiplinan siswa yang menjadi populasi tergolong cukup tinggi dari skor ideal yang mungkin dicapai siswa yaitu 100. Data mengenai distribusi jawaban responden (terlampir) untuk tiap item soal menunjukkan bahwa rata-rata siswa memilih alternatif jawaban Selalu (5), Sering (4) dan Kadangkadang serta selebihnya memilih Jarang (2) dan Tidak Pernah (1).

Berdasarkan hal tersebut, dapat dikatakan bahwa rata-rata kedisiplinan belajar siswa di SD Negeri Nusa Harapan Permai Kota Makassar cukup baik. Namun, dilihat dari skor ideal yang mungkin dicapai yaitu 100, kedisiplinan siswa masih perlu ditingkatkan lagi. Hasil analisis data hasil belajar siswa yang diperoleh dari analisis dokumen hasil belajar menunjukkan bahwa rata-rata hasil belajar siswa sebesar 77,97. Berdasarkan pedoman pengkategorian Departemen Pendidikan dan Kebudayaan (Depdikbud) hasil belajar siswa yang datanya telah diolah menunjukkan bahwa hasil belajar siswa tergolong tinggi yaitu mencapai $83 \%$ dengan frekuensi sebesar 30 pada interval nilai $65-84$.

Hasil olah data dengan menggunakan analisis Korelasi Product Moment dari Pearson menunjukkan bahwa nilai rhitung sebesar 0,799 dan nilai $r$ tabel untuk $\mathrm{n}=36$ yaitu 0,329 . Nilai rhitung $>r$ tabel berarti terdapat pengaruh kedisiplinan belajar terhadap hasil belajar matematika siswa di SD Negeri Nusa Harapan Permai Kota Makassar yang menjadi populasi.

Untuk mengetahui seberapa besar pengaruhnya atau tingkat signifikannya, maka diuji dengan uji signifikan seperti telah dibahas diatas. Hasil uji signifikan dengan a $5 \%$ diperoleh thitung sebesar 7,746 dan ttabel 1,691. Berdasarkan hipotesis penelitian yang diajukan bahwa apabila rhitung $>$ rtabel atau thitung $>$ ttabel maka H0 ditolak dan $\mathrm{H} 1$ diterima. Hal ini berarti terdapat pengaruh yang signifikan kedisiplinan belajar terhadap hasil belajar Matematika siswa SD Negeri Nusa Harapan Permai Kota Makassar.

\section{SIMPULAN}

Setelah data hasil angket diolah, diperoleh nilai rata-rata kedisiplinan siswa sebesar 72, 22. Skor ini tergolong cukup tinggi dari skor ideal yang mungkin dicapai yaitu 100. Hasil olah data dokumentasi hasil belajar siswa menunjukkan rata-rata hasil belajar siswa sebesar 77,97. Hasil ini tergolong tinggi berdasarkan pedoman kategorisasi Departemen Pendidikan dan Kebudayaan karena frekuensi hasil belajar siswa paling banya pada interval 65 - 84 sekitar $83 \%$ dari keseluruhan total skor yang mungkin dicapai . Hasil analisis data dengan Korelasi Pearson Product Moment menunjukkan bahwa nilai rhitung sebesar 0,799 dan nilai rtabel Product Moment untuk $\mathrm{n}=36$ yaitu 0,329 . Hal ini berarti nilai rhitung $>$ rtabel sehingga dinyatakan terdapat pengaruh kedisiplinan belajar terhadap hasil belajar matematika siswa di SD Nusa Harapan Permai Kota Makassar. Hasil uji signifikan untuk $\alpha=0,5 \%$ diperoleh thitung sebesar 7,746. Nilai ttabel dengan dk n$2=36-2=34$, diperoleh ttabel $=1$, 691. Ini berart nilai thitung $>$ ttabel 50 berdasarkan hipotesis penelitian yang diajukan maka H0 ditolak dan $\mathrm{H} 1$ diterima.

Kedisiplinan belajar siswa masih perlu untuk ditingkatkan. Berbagai hal yang menyangkut kedisiplinan dari berbagai macam faktor yang mungkin mempengaruhi kedisiplinan tidak meningkat masih perlu untuk dibenahi. Melihat hasil dari penelitian ini bahwa kedisplinan itu sendiri mempunyai pengaruh yang positif terhadap peningkatan hasil belajar siswa, maka diharapkan antara guru dan orangtua mampu bekerja sama agar kedepannya kedisiplianan belajar siswa semakin meningkat sehingga diharapkan hasil belajarnya juga ikut meningkat. 


\section{DAFTAR PUSTAKA}

Anas, M., Kusmayadi, T. A., \& Suyono, S. (2013). Eksperimentasi Model Pembelajaran Think Pairshare Modifikasi Penemuan Terbimbing Berbantuan Microsoft Power Point Pada Pembelajaran Matematika Ditinjau dari Kedisiplinan Belajar. http://www.jurnal.fkip.uns.ac.id/index. $\mathrm{php} / \mathrm{s} 2 \mathrm{math} / \mathrm{article} / \mathrm{view} / 3500$

Aqib, Z. (2011). Pendidikan Karakter Membangun Perilaku Positif Anak Bangsa. Bandung: Yrama Widya

Baharuddin. (2010). Pendidikan dan Psikologi Perkembangan. Jogjakarta: Ar-Ruzz Media

Daryanto. (2015). Pengelolaan Budaya dan Iklim Sekolah. Yogyakarta: Gava Media.

Emzir. (2015). Metodologi Penelitian Pendidikan: Kualaitatif dan Kuantitatif. Jakarta: Raja Grafindo Persada

Hamalik, O. (2010). Psikologi Belajar dan Mengajar. Bandung: Sinar Baru Algensindo

Yudhawati, R., \& Dany, H. (2011). Teori-teori Dasar Psikologi Pendidikan. Jakarta: Prestasi Pustaka Publisher

Kompri. (2014). Manajemen Sekolah Teori dan Praktek. Bandung: Alfabeta.

Mahardika, T. B. (2011). Pengaruh Bimbingan Orang Tua dan Kedisiplinan Belajar Anak Terhadap Prestasi Belajar Siswa Kelas IV SD Negeri 1 Sulursari Tahun Ajaran 2010/2011 (Doctoral dissertation, Univerversitas Muhammadiyah Surakarta).

Mulyasa, E. (2005). Menjadi Kepala Sekolah Profesional. Bandung: Remaja Rosdakarya.

Pidarta, M. (2014). Landasan Kependidikan Stimulus Ilmu Pendidikan Bercorak Indonesia. Jakarta: Rineka Cipta

Saputro, E. (2015). Pengaruh Kedisiplinan dan Kemandirian Belajar Terhadap Prestasi Belajar Siswa Kelas IV SDN Wironanggan 01 Tahun 2014/2015 (Doctoral dissertation, Universitas Muhammadiyah Surakarta).

Safitri, D. (2012). Pengaruh Kedisiplinan Dan Minat Belajar Terhadap Prestasi Belajar Matematika Siswa Kelas V SD Muhammadiyah 3 Surakarta (Doctoral dissertation, Universitas Muhammadiyah Surakarta).

Siregar, S. (2012). Statistika Deskriptif untuk Penelitian: Dilengkapi Perhitungan Manual dan Aplikasi SPSS Versi 17. Jakarta: Rajawali Pers

Shochib. (2000). Pola Asuh Orangtua dalam Membantu Anak Mengembangkan Disiplin Diri. Jakarta: Rineka Cipta.

Sugiyono. (2013). Metode Penelitian Pendidikan Pendekatan Kuantitatif, Kualitatif dan $R \& D$. Bandung: Alfabeta

Sulistyani, A.T (ed,). (2011). Memahami Good Governance dalam Perspektif Sumber Daya Manusia. Yogyakarta: Gava Media

Suryabrata, S. (2003). Metodologi Penelitian. Jakarta: Raja Grafindo Persada

Suryabrata, S. (2012). Psikologi Pendidikan. Jakarta: RajaGrafindo Persada.

Wahyuni, E.R. (2014). Pengaruh Disiplin Menyeleaikan Tugas dan Rasa Ingin Tahu Siswa terhadap Prestasi Belajar Matematika di Kelas V SD Negeri 2 Sokanegara Tahun Pelajaran 2013/2014. ((Doctoral dissertation, Univerversitas Muhammadiyah Surakarta). 